\begin{tabular}{|l|l|}
\hline Postprint Version & 1.0 \\
\hline Journal website & http://vb23.bsl.nl/frontend/index.asp?custom product id=1388- \\
\hline Pubmed link & $\underline{ }$ \\
\hline DOI & \\
\hline
\end{tabular}

This is a NIVEL certified Post Print, more info at http://www.nivel.eu

\title{
Compensatie eigen risico: nooit van gehoord, maar ik denk wel dat ik er recht op heb.
}

\author{
MARGREET REITSMA-VAN ROOIJEN* ,JUDITH D. DE JONG*
}

*NIVEL, Postbus 1568, 3500 BN Utrecht, tel. 030-2729626, e-mail: m.reitsma@nivel.nl

\begin{abstract}
Er zijn veel verschillende vergoedings- en compensatieregelingen voor ziektegerelateerde uitgaven. Het is belangrijk dat dergelijke regelingen goed worden uitgevoerd, zodat er geen rechthebbenden zijn die de vergoeding of compensatie mislopen en zodat er geen mensen zijn die deze ten onrechte aanvragen of krijgen. In 2008 is de regeling compensatie eigen risico ingevoerd. Deze compensatie krijgen rechthebbenden in principe automatisch uitbetaald. Als men deze compensatie niet krijgt, maar er toch recht op denkt te hebben, kan men de compensatie alsnog aanvragen. Uit een evaluatie van deze compensatieregeling door de Nederlandse Zorgautoriteit (NZa) blijkt dat een groot deel (85\%) van deze aanvragen onterecht is. Dit grote aantal onterechte aanvragen leidt tot onnodig hoge uitvoeringskosten. Het huidige onderzoek laat zien dat degenen die toch recht denken te hebben op de compensatie en deze alsnog aan gaan vragen, lang niet altijd weten wat de regeling inhoudt. Ook zoeken zij nauwelijks informatie over deze regeling op. Om het percentage onterechte aanvragen en de extra uitvoeringskosten die dat met zich meebrengt terug te dringen, is het van belang om mensen beter te informeren over de compensatieregeling. Mogelijk reduceert dit ook het aantal rechthebbenden dat de compensatie ten onrechte niet krijgt.
\end{abstract}

\section{INLEIDING}

Het Nederlandse zorgstelsel kent veel verschillende vergoedings- en compensatieregelingen voor ziektegerelateerde uitgaven. Op 1 januari 2008 is er een nieuwe compensatieregeling ingevoerd: de compensatieregeling eigen risico. Deze compensatie wordt in principe automatisch uitbetaald en wijkt hiermee af van de meeste andere compensatieregelingen die niet automatisch worden uitbetaald. Uit onderzoek van de Nederlandse Zorgautoriteit (NZa) ${ }^{1}$ blijkt dat de uitvoering van deze regeling te wensen overlaat: een deel van de mensen had de compensatie ten onrechte (nog) niet gekregen (2,5\% van de rechthebbenden) en het percentage onterechte aanvragers was hoog (85\% van de 64.000 aanvragen). Dit roept de vraag op of men voldoende weet dat de compensatieregeling eigen risico bestaat en wat deze inhoudt. In het huidige onderzoek staat deze vraag centraal.

De compensatieregeling eigen risico is gelijktijdig met het verplichte eigen risico ingevoerd. Dit verplichte eigen risico heeft op 1 januari 2008 de no-claimteruggave vervangen. Het verplichte eigen risico bedroeg in $2008 € 150$,- per jaar. Dat houdt in dat mensen in 2008 de eerste $€ 150$,- aan zorgkosten zelf moesten betalen. Doel van het eigen risico is tweeledig. Er wordt mee beoogd dat mensen zich bewuster worden van de kosten van zorg en daarom minder snel gebruik zullen maken van zorg. ${ }^{2,3}$ Een tweede doel is een financieringsverschuiving; door de invoering van het eigen risico nemen de collectieve uitgaven af en nemen de particuliere uitgaven toe. Deze financieringsverschuiving bedraagt naar schatting ruim 1,45 miljard euro. ${ }^{4}$ 
Chronisch zieken en mensen met een handicap hebben vaak hogere zorgkosten dan anderen. Mensen met meerjarige, onvermijdbare kosten, worden door de "compensatieregeling eigen risico" financieel tegemoet gekomen voor het verplichte eigen risico. De hoogte van de compensatie is in 2008 vastgesteld op $€$ 47,per jaar. Op deze manier wil de overheid mensen met meerjarige, onvermijdbare kosten net zoveel eigen risico laten betalen als mensen die deze kosten niet hebben.

Het ministerie van Volksgezondheid, Welzijn en Sport (VWS) bepaalt welke groepen een compensatie krijgen. In 2008 kwamen verzekerden die in 2006 en 2007 meer dan 180 dagdoseringen van een bepaald geneesmiddel voorgeschreven kregen in aanmerking voor compensatie van het eigen risico. Compensatie van het eigen risico geldt uitsluitend voor gebruik van geneesmiddelen buiten zorginstellingen. Daarnaast kwamen in 2008 verzekerden die op 1 juli 2008 tenminste een half jaar in een AWBZ-instelling verbleven in aanmerking voor de compensatie. AWBZ-instellingen zijn verpleeghuizen, instellingen voor lichamelijk gehandicapten, instellingen voor verstandelijk gehandicapten, psychiatrische ziekenhuizen, verzorgingshuizen en instellingen voor beschermd wonen. Niet alle chronisch zieken en gehandicapten komen dus in aanmerking voor de compensatie van het eigen risico. Van de 3,25 miljoen personen in Nederland met een chronische ziekte of handicap, ${ }^{5}$ kwamen er in 2008 1,85 miljoen in aanmerking voor de compensatie.

Het Centraal Administratiekantoor (CAK) heeft in september 2008 iedereen waarvan zij meenden dat die in aanmerking kwam voor de compensatie een brief gestuurd. Om te bepalen wie in aanmerking kwamen voor de compensatie op basis van medicijngebruik was het CAK afhankelijk van de gegevens van de zorgverzekeraars over 2006 en 2007. De selectie van degenen die recht hebben op compensatie vanwege verblijf in een AWBZ-instelling werd bepaald op basis van de bestanden van het CAK met personen die in AWBZ-instellingen verblijven. Iedereen die een brief had ontvangen, kreeg de compensatie over 2008 automatisch van het CAK. Wanneer men geen brief had ontvangen en wel in aanmerking dacht te komen voor compensatie kon men deze aanvragen bij het CAK. Deze aanvraag kon men doen via het aanvraagformulier compensatie eigen risico van het CAK. Op dit formulier kon men, door een vragenboom in te vullen, erachter komen of men mogelijk recht had op de compensatie. Ook kon men buiten dit aanvraagformulier om een aanvraag indienen, door bijvoorbeeld een brief te sturen.

Het is van belang dat de uitvoering van deze regeling goed verloopt, om zowel onterechte aanvragen als het missen van rechthebbenden te voorkomen. Voor een goede uitvoering is men in de eerste plaats afhankelijk van de kwaliteit van registratiesystemen. Uit onderzoek van de NZa ${ }^{1}$ blijkt dat deze kwaliteit te wensen overliet. Bij de uitbetaling van de compensatie was er halverwege maart 2009 een aanzienlijke vertraging opgetreden: 1,85 miljoen mensen kwamen in 2008 in aanmerking voor de compensatie, 2,5\% hiervan had de compensatie nog niet uitbetaald gekregen. ${ }^{1}$ De oorzaak was dat een aantal zorgverzekeraars onvolledige farmaciebestanden had aangeleverd. Ook ontbraken rekeningnummers en/of de Naam/Adres/Woonplaats- gegevens. Hierop zijn verscheidene acties ingezet, waarmee het aantal mensen dat wel recht heeft op de compensatie, maar deze niet heeft gekregen, succesvol is gereduceerd. Niet te achterhalen is of er mensen waren die recht op de compensatie hadden, maar de compensatie vanwege onjuistheden in de registratiesystemen niet toegewezen kregen.

Voor een goede uitvoering van de regeling is het ook van belang dat mensen op de hoogte zijn van de compensatieregeling. Als mensen goed geïnformeerd zijn, zullen zij de compensatie alsnog aanvragen als ze deze ten onrechte niet hebben gekregen. Ook is dan de kans minder groot dat mensen de compensatie ten onrechte aanvragen. Uit het onderzoek van de NZa blijkt dat het aantal onterechte aanvragen aanzienlijk is: het CAK heeft ruim 64.000 aanvragen ontvangen waarvan $85 \%$ is afgewezen, omdat deze niet voldeden aan de wettelijke criteria voor de compensatie. ${ }^{1}$ Dit roept de vraag op of bij de invoering van de compensatieregeling mensen voldoende op de hoogte zijn gebracht van het bestaan van de regeling en de inhoud van de regeling. Deze vraag is interessant omdat de compensatieregeling eigen risico afwijkt van veel regelingen binnen de gezondheidszorg. Bij de meeste regelingen ligt het initiatief bij de potentiële gebruikers. Zij moeten in de meeste gevallen zelf een aanvraag indienen. Het is dus interessant om te achterhalen hoe de regeling compensatie eigen risico werkt. Mogelijk zou er bij meerdere regelingen voor gekozen kunnen worden om het initiatief niet bij de gebruikers te leggen. Uit onderzoek blijkt namelijk dat mensen veelal geen gebruik maken van regelingen waar zij wel gebruik van zouden kunnen maken. ${ }^{6} \mathrm{Bij}$ bijvoorbeeld de regeling Buitengewone Uitgaven (BU) blijken de zogenaamde rechthebbende nietgebruikers gemiddeld iets jonger en lager opgeleid te zijn dan degenen die de BU wel benutten. Ook hebben de rechthebbende niet-gebruikers vaker een salaris rondom het sociaal minimum. Dit kan gezien 
worden als een onrechtvaardige verdeling van middelen. Het initiatief voor gebruik van de regeling weghalen bij de potentiële gebruiker zou deze onrechtvaardige verdeling van middelen kunnen voorkomen. Het is dus belangrijk om te weten of bij de compensatieregeling eigen risico het niet-gebruik lager is dan bij regelingen waarbij men zelf een aanvraag in moet dienen. Ook is het belangrijk om te weten of de groep rechthebbende niet-gebruikers afwijkt van degenen die de compensatie eigen risico wel krijgen wat betreft kenmerken zoals bijvoorbeeld leeftijd en opleiding. Echter, wanneer mensen een aanvraag niet zelf hoeven indienen, zoals bij de compensatie van het eigen risico, is het mogelijk dat de overheid vertrouwt op de kwaliteit van de registratiesystemen en te weinig informatie verstrekt over het bestaan van de regeling, wanneer men er recht op heeft en hoe men de compensatie aan kan vragen. Dit kan leiden tot onterechte aanvragen van de compensatie en kan ertoe leiden dat mensen de compensatie eigen risico ten onrechte niet aanvragen.

In het huidige onderzoek willen we dan ook de volgende vraag beantwoorden: zijn mensen bekend met de compensatieregeling en zoeken zij informatie over de regeling op? Bij het beantwoorden van deze vraag willen we een onderscheid maken tussen mensen die een brief hebben gehad dat ze recht hebben op de compensatie van het eigen risico en mensen die deze brief niet hebben gehad. Mensen die de brief niet hebben gehad, zijn mogelijk mensen die de compensatie ten onrechte niet krijgen of (ten onrechte) aanvragen. Daarom is het van belang dat ook deze groep goed geïnformeerd is. Van de groep mensen die geen brief hebben gehad, willen we weten in hoeverre de mensen die wel recht op de compensatie denken te hebben bekend zijn met de regeling. Ook willen we weten in hoeverre de mensen die de compensatie alsnog aan willen vragen bekend zijn met de regeling. Dit leidt tot de volgende drie onderzoeksvragen:

In hoeverre zijn mensen die wel een brief hebben gehad en mensen die geen brief hebben gehad op de hoogte van de compensatie van het eigen risico en zoeken zij hierover informatie op?

In hoeverre zijn mensen die denken recht te hebben op de compensatie op de hoogte van de compensatie van het eigen risico en zoeken zij hierover informatie op?

In hoeverre zijn mensen die de compensatie alsnog aan gaan vragen op de hoogte van de compensatie van het eigen risico en zoeken zij hierover informatie op?

Bij het beantwoorden van deze vragen is een onderscheid gemaakt tussen een groep chronisch zieken en gehandicapten en een groep die representatief is voor de algemene bevolking in Nederland. We verwachten dat de regeling relatief onbekend is bij de bevolking, en dat chronisch zieken en gehandicapten bekender zijn met de regeling dan mensen uit de algemene bevolking.

Methode

We hebben vragen over de compensatie van het eigen risico voorgelegd aan leden van twee panels van het NIVEL (Nederlands instituut voor onderzoek van de gezondheidszorg): het Consumentenpanel

Gezondheidszorg en het Nationaal Panel Chronisch zieken en Gehandicapten (NPCG).

Het Consumentenpanel Gezondheidszorg bestaat uit ruim 2800 mensen. De samenstelling van dit panel is representatief voor de algemene bevolking in Nederland. In oktober 2008 hebben 1376 panelleden een vragenlijst ontvangen. Hierin werden onder andere vragen over de compensatie van het eigen risico gesteld. In totaal retourneerden 991 mensen de vragenlijst (respons 72\%).

Het NPCG bestaat uit zelfstandig wonende mensen met een medisch gediagnosticeerde chronische aandoening en/of ernstige lichamelijke beperkingen van vijftien jaar en ouder. Eveneens in oktober 2008 hebben 3922 panelleden een vragenlijst ontvangen. Hierin werden dezelfde vragen over de compensatie van het eigen risico gesteld als die aan de leden van het Consumentenpanel werden gesteld. In totaal retourneerden 3416 mensen de vragenlijst (respons 87\%). De respondenten van het NPCG-panel zijn bij alle analyses zodanig gewogen dat de verhouding tussen chronisch zieken en mensen met een handicap onder de respondenten gelijk is aan deze verhouding in de populatie. ${ }^{7}$

Panelleden werd gevraagd in hoeverre ze bekend waren met de regeling compensatie eigen risico ('bekendheid') en of ze informatie hadden opgezocht over de compensatieregeling ('informatie'). Ook werd gevraagd of ze een brief hadden gehad waarin stond dat ze recht hadden op de compensatie ('brief'). Degenen die aangaven dat ze geen brief hadden gehad, werd gevraagd of ze dachten dat ze wel recht hadden op de compensatie ('recht'). Aan hen die dachten recht te hebben op de compensatie of dit niet wisten, werd gevraagd of ze de compensatie alsnog aan gingen vragen ('aanvragen’).

De data zijn geanalyseerd door middel van (multinomiale) logistische regressieanalyses. Allereerst zijn beschrijvende analyses uitgevoerd. Als afhankelijke variabelen zijn in afzonderlijke analyses de variabelen 'brief', 'recht' en 'aanvragen' meegenomen. Daarna zijn de drie onderzoeksvragen beantwoord door 
analyses uit te voeren met 'bekendheid' en 'informatie' als afhankelijke variabelen en respectievelijk 'brief', 'recht' en 'aanvragen' als onafhankelijke variabelen.

Bij alle analyses is panellidmaatschap meegenomen als onafhankelijke variabele. Ook is bij alle analyses gecorrigeerd voor verschillen in samenstelling tussen beide panels wat betreft leeftijd, geslacht en opleiding door deze kenmerken als onafhankelijke variabelen mee te nemen. Dit betekent dat verschillen op afhankelijke variabelen niet kunnen worden toegeschreven aan verschillen tussen beide panels wat betreft leeftijd, geslacht en opleiding.

Om de regressiecoëfficiënten te kunnen interpreteren, wordt hieronder per variabele aangegeven welke waarden de verschillende antwoordmogelijkheden hebben. Panellidmaatschap heeft twee categorieën (1=NPCG, 2 = Consumentenpanel Gezondheidszorg). Leeftijd is gemeten in jaren, opleiding is gemeten op een schaal van 1 (geen onderwijs) tot en met 10 (post academisch onderwijs), geslacht heeft twee antwoordmogelijkheden $(0=$ man, $1=$ vrouw $)$. 'Bekendheid' heeft vier antwoordmogelijkheden $(1=\mathrm{Ik}$ heb er nooit van gehoord, $2=\mathrm{Ik}$ heb er wel eens van gehoord maar weet niet wanneer ik recht heb op compensatie van het verplichte eigen risico, $3=\mathrm{Ik}$ heb er wel eens van gehoord en weet ongeveer wanneer ik recht heb op compensatie van het verplichte eigen risico, $4=\mathrm{Ik}$ weet precies wanneer ik recht heb op compensatie van het verplichte eigen risico). 'Informatie' en 'brief' hebben twee antwoordmogelijkheden ( $1=$ nee, $2=j a)$. 'Recht' en 'aanvragen' hebben drie antwoordmogelijkheden (1=nee, $2=$ ja, $3=$ weet niet).

Alle significante effecten die worden genoemd hebben een p-waarde lager dan 0,05. Bij de multinomiale logistische regressies met 'bekendheid met de regeling' als afhankelijke variabele hebben we de vierde antwoordcategorie "ik weet precies wanneer ik recht heb op compensatie van het verplichte eigen risico" als referentiecategorie genomen. Bij de afhankelijke variabelen met nee, ja en weet niet als antwoordcategorieën, hebben we "ja” als referentiecategorie genomen.

\section{RESULTATEN}

Van de algemene bevolking ( $\mathrm{N}=957)$ had 22,9\% een brief van het CAK gehad, omdat zij recht hadden op de compensatie van het eigen risico. Van de chronisch zieken en gehandicapten ( $N=3294)$ had 43,2\% deze brief gehad (referentiegroep: geslacht $=0,60$, leeftijd $=60,9$ jaar, opleiding $=4,8$ ). Mensen met een chronische ziekte of handicap hebben, zoals verwacht, significant vaker een brief gekregen dan mensen uit de algemene bevolking, regressiecoëfficiënt $(B)=-0,94$. Daarnaast is er een positief effect van leeftijd $(B=$ $0,02)$ : Hoe ouder men is, hoe vaker men een brief krijgt. Dit hangt samen met het feit dat ouderen vaker langdurig diverse geneesmiddelen gebruiken en op grond daarvan recht hebben op compensatie van het eigen risico. Mensen met een hoge opleiding hebben minder vaak een brief gekregen dan mensen met een lage opleiding $(\mathrm{B}=-0,07)$. Een mogelijke verklaring hiervoor is dat mensen met een chronische ziekte of handicap gemiddeld genomen lager zijn opgeleid dan mensen zonder chronische ziekte of handicap. ${ }^{8,9}$

Ruim één op de tien mensen van de algemene bevolking (12,7\%) en bijna een derde van de chronisch zieken en gehandicapten (31,7\%) die geen brief hebben gehad, denken recht te hebben op de compensatie, zie Tabel 1. Respectievelijk een kwart (26,0\%) en bijna de helft $(45,2 \%)$ van degenen die geen brief hebben gehad, zegt niet te weten of ze recht hebben op compensatie. Aan degenen die denken recht te hebben op de compensatie of dit niet weten, is gevraagd of men de compensatie alsnog aan gaat vragen. Ruim een vijfde van de algemene bevolking (22,5\%) en ruim een kwart van de chronisch zieken en gehandicapten (29,9\%) zegt dit te gaan doen.

Het blijkt dat chronisch zieken en mensen met een handicap significant vaker dan de algemene bevolking aangeven dat zij naar hun mening wel recht hebben op de compensatie $(B=1,9)$ en deze aan gaan vragen $(\mathrm{B}=0,76)$.

\section{[TABEL 1]}

In hoeverre zijn mensen die wel een brief hebben gehad en mensen die geen brief hebben gehad op de hoogte van de compensatie van het eigen risico en zoeken zij hierover informatie op?

Degenen met brief geven significant vaker aan precies te weten wanneer men recht heeft op de compensatie ( $B=-3,03$ ) in vergelijking met degenen zonder brief. De mensen die geen brief hebben gehad, lijken niet erg bekend te zijn met de regeling. Van hen zegt, zowel van de algemene bevolking als van de chronisch zieken en gehandicapten, ongeveer de helft nog nooit van de regeling gehoord te hebben (respectievelijk 50,6\% en 49,7\%, zie Tabel 2). Van degenen die wel een brief gehad hebben zegt ruim twee 
vijfde (41,4\% van de algemene bevolking en $45,4 \%$ van de chronisch zieken en gehandicapten) precies te weten wanneer ze recht hebben op deze compensatie.

\section{[TABEL 2]}

Referentiegroep: geslacht $=0,59$, leeftijd $=60,8$, opleiding $=4,8$

Bijna niemand heeft informatie opgezocht over het recht op compensatie van het verplichte eigen risico. Van de algemene bevolking zoekt gemiddeld minder dan een tiende $(7,7 \%$ als men een brief heeft gehad en $5,1 \%$ als men geen brief heeft gehad) informatie op. Van de chronisch zieken en gehandicapten zoekt gemiddeld genomen iets meer dan één op de tien (13,7\% als men een brief heeft gehad en 9,2\% als men geen brief heeft gehad) informatie op. Degenen die een brief hebben gehad zoeken significant vaker informatie op dan degenen die geen brief hebben gehad $(B=0,45)$. Ook chronisch zieken en gehandicapten zoeken significant vaker informatie op dan mensen uit de algemene bevolking $(\mathrm{B}=-0,64)$. Leeftijd, geslacht en opleiding hebben geen significant effect op het zoeken van informatie.

Aan degenen die informatie hebben opgezocht, is gevraagd of men informatie heeft gevonden. 6,5\% van de chronisch zieken en gehandicapten en 4,8\% van de algemene bevolking geeft aan dat zij geen informatie hebben gevonden. Mensen met een lagere opleiding kruisen dit significant vaker aan dan mensen met een hoge opleiding $(\mathrm{B}=-0,47)$.

In hoeverre zijn mensen die denken recht te hebben op de compensatie op de hoogte van de compensatie van het eigen risico en zoeken zij hierover informatie op?

Weten degenen die menen recht te hebben op de compensatie wat de regeling inhoudt en hebben zij informatie over de regeling opgezocht. Om deze vragen te beantwoorden hebben we twee (multinomiale) logistische regressieanalyses uitgevoerd met als afhankelijke variabelen respectievelijk bekendheid met de regeling en informatie zoeken over de regeling.

\section{[TABEL 3]}

Ruim twee vijfde (43,2\%) van de algemene bevolking en van de chronisch zieken en gehandicapten $(42,2 \%)$ die geen brief hebben gehad, denkt wel recht op compensatie te hebben, maar geeft aan nog nooit van de regeling te hebben gehoord, zie Tabel 3. Degenen die recht op compensatie denken te hebben, geven significant vaker aan informatie te hebben gezocht dan degenen die geen recht op compensatie denken te hebben $(B=5,24)$. Dit is opvallend: degenen die er recht op denken te hebben, zoeken wel vaker informatie op dan degenen die er geen recht op denken te hebben, of dit niet weten, maar zij zijn niet bekender met de regeling. Dit suggereert dat zij geen of geen bruikbare informatie hebben gevonden.

In hoeverre zijn mensen die de compensatie alsnog aan gaan vragen op de hoogte van de compensatie van het eigen risico en zoeken zij hierover informatie op?

Een andere interessante vraag is of mensen die zeggen de compensatie alsnog aan te gaan vragen, bekend zijn met de regeling en informatie over de regeling opzoeken.

Van degenen die zeggen dat zij de compensatie alsnog gaan aanvragen of dit nog niet weten, heeft ongeveer twee vijfde (38,7\% van de algemene bevolking en 41,6\% van de chronisch zieken en gehandicapten) nog nooit van de regeling gehoord, zie Tabel 4 . Slechts ongeveer een tiende (9,1\%) van de algemene bevolking en een zevende (14,0\%) van de chronisch zieken en gehandicapten weet precies wanneer zij recht hebben op compensatie van het verplichte eigen risico. Mensen die zeggen dat zij de compensatie alsnog aan gaan vragen of dit nog niet weten, zeggen wel vaker dan degenen die dit niet doen precies te weten wanneer zij recht hebben op de compensatie $(B=1,11)$. Degenen die zeggen de compensatie alsnog aan te gaan vragen of dit nog niet weten, zoeken ook significant vaker informatie op dan degenen die dit niet doen of niet weten $(B=2,71)$. Echter, nog steeds zoekt bijna driekwart geen informatie op.

\section{DISCUSSIE}

De resultaten laten zien dat een aanzienlijk deel van de algemene bevolking en van de chronisch zieken en gehandicapten niet bekend is met de compensatieregeling. Ook zoekt slechts een klein deel van de mensen informatie op over de regeling. Daarbij geven sommigen ook aan wel informatie te zoeken, maar deze niet te kunnen vinden. 
Onbekendheid van de compensatieregeling kan ertoe leiden dat de regeling onderbenut wordt. Uit een onderzoek naar de uitvoering van de regeling door de NZa blijkt dat de uitvoering zodanig verloopt dat een groep van rechthebbenden (nog) geen compensatie ontvangt als zij die niet zelf bij het CAK aanvragen. Door de onbekendheid van de regeling is het niet ondenkbaar dat deze rechthebbenden de compensatie niet alsnog gaan aanvragen. Het gevolg hiervan is dat zij de compensatie ten onrechte mislopen. Het percentage rechthebbende niet-gebruikers lijkt bij de regeling compensatie eigen risico echter veel lager te liggen dan bij de BU-regeling, een regeling waarbij men de vergoeding niet automatisch krijgt, maar zelf een aanvraag voor deze vergoeding in moet dienen: Onderzoek laat zien dat bij de BU-regeling $60 \%$ van de rechthebbenden geen gebruik heeft gemaakt van de BU-regeling 2004, bij de compensatieregeling eigen risico ligt dit percentage veel lager. Dit is een aanwijzing dat bij een regeling waarbij de compensatie automatisch uit wordt betaald, er minder rechthebbende niet-gebruikers zijn, dan bij een regeling waarbij men de vergoeding zelf moet aanvragen. Op basis van ons onderzoek kunnen we geen uitspraak doen over of degenen die de compensatie eigen risico niet krijgen afwijken van degenen die de compensatie eigen risico wel krijgen wat betreft kenmerken zoals leeftijd en opleiding. Wel zien we dat van degenen die informatie hebben opgezocht over de compensatieregeling, lager opgeleiden vaker dan hoger opgeleiden aankruisen dat zij geen informatie hebben gevonden. Echter, de kans op een onrechtvaardige verdeling van middelen ligt naar verwachting lager bij een regeling waarbij de compensatie automatisch uit wordt betaald dan bij een regeling waarbij dit niet automatisch gaat.

Onbekendheid met de regeling kan er ook toe leiden dat mensen juist doordat zij niet goed zijn geïnformeerd, ten onrechte compensatie aanvragen. Degenen die de compensatie gaan aanvragen zijn niet bekender met de regeling, maar zoeken wel vaker informatie op dan degenen die de compensatie niet aan gaan vragen. Het grootste deel zoekt echter helemaal geen informatie op.

Om geen rechthebbenden mis te lopen en het aantal onterechte aanvragen te reduceren, zijn twee zaken van belang. Om geen rechthebbenden mis te lopen is het cruciaal dat de kwaliteit van de registratiesystemen voldoende is. Om het aantal onterechte aanvragen te reduceren is het van belang om de bekendheid met de compensatieregeling te vergroten. Alleen het beschikbaar stellen van informatie lijkt onvoldoende. Uit ons onderzoek blijkt namelijk dat het percentage mensen dat bekend is met de compensatieregeling hoger is dan het percentage mensen dat informatie opzoekt. Dit betekent waarschijnlijk dat mensen op een andere manier op de hoogte zijn gesteld van de regeling, bijvoorbeeld door de brief van het CAK. Informatie moet beschikbaar zijn, maar moet mensen ook bereiken als ze niet actief zoeken. In dat kader is het interessant om te onderzoeken welke informatiebronnen mensen gebruiken wanneer zij informatie op willen zoeken over compensatie van het eigen risico en hoe dit samenhangt met bijvoorbeeld leeftijd, geslacht en opleiding. In aanvulling daarop kan gekeken worden welke groepen geen informatie kunnen vinden en waarom niet. Kennis over de bronnen die mensen gebruiken en welke groepen geen informatie kunnen vinden is nodig als mensen bereikt moeten worden met informatie.

Om zoveel mogelijk onterechte aanvragen te voorkomen, zouden mensen gestimuleerd kunnen worden om deze aanvraag via het aanvraagformulier compensatie eigen risico van het CAK te doen. In 2008 kon men ook buiten dit aanvraagformulier om een aanvraag indienen. Het is niet duidelijk welk deel van de aanvragen via dit aanvraagformulier is gedaan. Ook is niet duidelijk wat het percentage onterechte aanvragen was bij het aanvraagformulier en wat dit percentage was wanneer men het aanvraagformulier niet gebruikte.

Opvallend is dat een deel van de mensen zegt wel recht te hebben op de compensatie, maar deze niet aan gaat vragen of dit nog niet weet. Waarom zij de compensatie niet aanvragen is onbekend. Uit ons onderzoek weten we hoeveel mensen zeggen dat zij de compensatie alsnog gaan aanvragen. Het is de vraag of zij dit ook daadwerkelijk doen.

We kunnen concluderen dat, om de compensatie bij alle rechthebbenden terecht te laten komen en onterechte aanvragen te voorkomen, de compensatieregeling eigen risico meer bekend dient te worden.

Hierbij moet worden opgemerkt dat mensen niet zelf op zoek lijken te gaan naar informatie. Daarom is het van belang dat de informatie dicht bij de mensen wordt gebracht. Zeker nu vanaf 2009 meer mensen in aanmerking komen voor de compensatie (ook mensen die hoge kosten maken voor medisch-specialistische zorg of ziekenhuiszorg komen dan in aanmerking), is een goed voorlichtingstraject van belang. 


\section{COMPENSATION ARRANGEMENT FOR THE OBLIGATORY DEDUCTIBLE: NEVER HEARD ABOUT, BUT I THINK I AM ENTITLED TO IT.}

There are many different compensatory arrangements for health related expenses. It is important that these are executed correctly, to prevent that people who are entitled to compensation do not receive the compensation and that people claim the compensation who are not entitled to receive a compensation. In 2008, the compensation arrangement for the obligatory deductible has been introduced. This compensation is paid automatically. People who do not receive the compensation but regard themselves as rightful claimants can ask for the compensation. An evaluation of the compensation arrangement of the Dutch Healthcare Authority shows that many requests for compensation of the obligatory deductible are not justified (85\%). This high number of not-justifiable requests leads to unnecessary cost of work. Current research shows that people who regard themselves as rightful claimants and ask for the compensation do not exactly know the ins and outs of the compensation arrangement. They also hardly look for information about this arrangement. To reduce the percentage of not-justifiable requests and the extra cost of work this causes, it is important to provide people with more information about the compensation arrangement for the obligatory deductible. This is expected to reduce also the number of people who are entitled to compensation but do not receive it.

\section{LITERATUUR}

1. Nederlandse Zorgautoriteit. Monitor Eigen risico 2008. Utrecht: NZa, 2009.

2. Kok J, Houkes A. Inkomensafhankelijk eigen risico remt zorgkosten. ESB 2009;94(4555):138-40.

3. Kleef $R$ van, Ven $W$ van de, Vliet $R$ van. Een effectiever eigen risico in de zorg. ESB 2007; 92 (4515): 459-61.

4. Ministerie van VWS. reactie op eerste evaluatie Zorgverzekeringswet, persbericht 4. Den Haag, Ministerie van VWS, 2009.

5. Pomp M, Smit M, Boo A. de. Compensatieregeling chronisch zieken \& gehandicapten Onderzoek naar een regeling ter compensatie van chronisch zieken en gehandicapten voor ziektegerelateerde meerkosten. Zeist: Vektis, 2008.

6. Pannekeet-Helsen MJE, Rijken PM. Financiële situatie van chronisch zieken en gehandicapten 2004/2005. Utrecht: NIVEL, 2005.

7. $\quad$ Brink-Muinen A van den, Rijken M., Spreeuwenberg P, Heijmans M. Kerngegevens Maatschappelijke Situatie 2008. Utrecht: NIVEL, 2009.

8. Calsbeek H, Rijken M, Bekker MJTM, Kerssens JJ, Dekker J, Berge Henegouwen GP van. The social position of adolescents and young adults with chronic digestive disorders. Eur J Gastroenterology Hepatology 2002;14:543-9.

9. Sociaal en Cultureel Planbureau. Meedoen met beperkingen. Rapportage gehandicapten 2007. Den Haag: SCP, 2007. 


\section{TABELLEN}

Tabel 1. Hoeveel mensen van degenen die geen brief gehad hebben denken recht te hebben op de compensatie en hoeveel mensen gaan deze compensatie aanvragen (percentages).

Algemene bevolking Chronisch zieken en gehandicapten $(\mathrm{N}=733)$ $(\mathrm{N}=1668)$

\begin{tabular}{llr}
\hline $\begin{array}{l}\text { Heeft u naar uw mening wel recht op de } \\
\text { compensatie van } € 47 ?^{1}\end{array}$ & \\
Nee & 61,3 & 23 \\
Ja & 12,7 & 31,7 \\
Weet niet & 26,0 & 45,2 \\
& Algemene bevolking & Chron \\
& $(\mathrm{N}=251)$ & $(\mathrm{N}=1213)$ \\
Gaat u alsnog de compensatie van $€ 47$ & & \\
aanvragen? & & \\
Nee & 18,7 & 11,6 \\
Ja & 22,5 & 29,9 \\
Weet niet & 58,8 & 58,5
\end{tabular}

${ }^{1}$ Referentiegroep: geslacht $=0,60$, leeftijd $=58,8$, opleiding $=5,0$. Bij deze analyse zijn alleen de mensen die geen brief hebben gehad meegenomen.

${ }^{2}$ Referentiegroep: geslacht $=0,61$, leeftijd $=60,2$, opleiding $=4,7$. Bij deze analyse zijn alleen de mensen die denken recht te hebben op de compensatie of dit niet weten meegenomen.

Tabel 2. In hoeverre is men bekend is met de regeling compensatie van het eigen risico en zoekt men informatie over de regeling op?(percentages)

\begin{tabular}{|c|c|c|c|c|}
\hline & \multicolumn{2}{|c|}{$\begin{array}{l}\text { Algemene } \\
\text { bevolking }\end{array}$} & \multicolumn{2}{|c|}{$\begin{array}{l}\text { Chronisch zieken en } \\
\text { gehandicapten }\end{array}$} \\
\hline & $\begin{array}{r}\text { wel } \\
\text { brief }\end{array}$ & $\begin{array}{c}\text { geen } \\
\text { brief }\end{array}$ & wel brief & geen brief \\
\hline \multicolumn{5}{|l|}{ Bekendheid } \\
\hline & $\mathrm{N}=197$ & $N=754$ & $N=1468$ & $N=1758$ \\
\hline Ik heb er nooit van gehoord & 12,1 & 50,6 & 10,9 & 49,7 \\
\hline $\begin{array}{l}\text { Ik heb er wel eens van gehoord maar weet niet wanneer ik recht heb } \\
\text { op compensatie van het verplichte eigen risico }\end{array}$ & 14,9 & 29,3 & 12,8 & 27,6 \\
\hline $\begin{array}{l}\text { Ik heb er wel eens van gehoord en weet ongeveer wanneer ik recht } \\
\text { heb op compensatie van het verplichte eigen risico }\end{array}$ & 31,5 & 11,8 & 31,0 & 12,7 \\
\hline $\begin{array}{l}\text { Ik weet precies wanneer ik recht heb op compensatie van het } \\
\text { verplichte eigen risico }\end{array}$ & 41,4 & 8,3 & 45,4 & 10,0 \\
\hline \multicolumn{5}{|l|}{ Informatie } \\
\hline & $N=198$ & $N=744$ & $N=1474$ & $N=1752$ \\
\hline Informatie opgezocht & 7,7 & 5,1 & 13,7 & 9,2 \\
\hline
\end{tabular}


Reitsma-van Rooijen, M., Jong, J. de. Compensatie eigen risico: nooit van gehoord, maar ik denk weldat it recht op heb. TSG: Tijdschrift voor Gezondheidswetenschappen: 2011, 89(2), 121-128

Tabel 3. Zijn mensen die denken recht te hebben op de compensatie bekend met de compensatieregeling en hebben zij informatie over de regeling opgezocht? (Percentages)

\begin{tabular}{|c|c|c|c|c|c|c|}
\hline & \multicolumn{3}{|c|}{$\begin{array}{l}\text { Algemene bevolking Recht } \\
\text { op compensatie }\end{array}$} & \multicolumn{3}{|c|}{$\begin{array}{l}\text { Chronisch zieken en } \\
\text { gehandicapten Recht op } \\
\text { compensatie }\end{array}$} \\
\hline & nee & ja & weet niet & nee & ja & weet niet \\
\hline \multicolumn{7}{|l|}{ Bekendheid } \\
\hline & $N=473$ & $N=81$ & $N=167$ & $N=416$ & $N=475$ & $N=759$ \\
\hline Ik heb er nooit van gehoord & 50,2 & 43,2 & 58,2 & 47,2 & 42,2 & 60,6 \\
\hline $\begin{array}{l}\text { Ik heb er wel eens van gehoord maar weet niet } \\
\text { wanneer ik recht heb op compensatie van het } \\
\text { verplichte eigen risico }\end{array}$ & 24,2 & 34,8 & 35,3 & 18,5 & 27,7 & 29,9 \\
\hline $\begin{array}{l}\text { Ik heb er wel eens van gehoord en weet } \\
\text { ongeveer wanneer ik recht heb op compensatie } \\
\text { van het verplichte eigen risico }\end{array}$ & 17,3 & 15,4 & 4,7 & 18,6 & 17,2 & 5,5 \\
\hline $\begin{array}{l}\text { Ik weet precies wanneer ik recht heb op } \\
\text { compensatie van het verplichte eigen risico }\end{array}$ & 8,4 & 6,6 & 1,9 & 15,7 & 12,9 & 4,0 \\
\hline \multicolumn{7}{|l|}{ Informatie } \\
\hline & $N=467$ & $\mathrm{~N}=84$ & $N=170$ & $N=420$ & $N=468$ & $N=757$ \\
\hline Informatie opgezocht & 3,7 & 16,6 & 1,4 & 5,7 & 23,9 & 2,3 \\
\hline
\end{tabular}

Noot: Bij deze analyses zijn alleen de mensen die geen brief hebben gehad meegenomen

Referentiegroep: geslacht $=0,60$, leeftijd $=58,7$, opleiding $=5,0$

Tabel 4. Zijn mensen die zeggen de compensatie alsnog te gaan aanvragen bekend met de compensatieregeling en hebben zij informatie over de regeling opgezocht? (Percentages)

\begin{tabular}{|c|c|c|c|c|c|c|}
\hline & \multicolumn{3}{|c|}{$\begin{array}{l}\text { Algemene bevolking } \\
\text { Alsnog aanvragen }\end{array}$} & \multicolumn{3}{|c|}{$\begin{array}{l}\text { Chronisch zieken en } \\
\text { gehandicapten Alsnog aanvragen }\end{array}$} \\
\hline & nee & ja & weet niet & nee & ja & weet niet \\
\hline \multicolumn{7}{|l|}{ Bekendheid } \\
\hline & $N=48$ & $N=61$ & $N=136$ & $N=165$ & $N=330$ & $N=706$ \\
\hline Ik heb er nooit van gehoord & 50,0 & 38,7 & 54,5 & 54,4 & 41,6 & 59,1 \\
\hline $\begin{array}{l}\text { Ik heb er wel eens van gehoord maar weet niet } \\
\text { wanneer ik recht heb op compensatie van het } \\
\text { verplichte eigen risico }\end{array}$ & 32,3 & 33,9 & 35,7 & 27,6 & 28,6 & 30,4 \\
\hline $\begin{array}{l}\text { Ik heb er wel eens van gehoord en weet ongeveer } \\
\text { wanneer ik recht heb op compensatie van het } \\
\text { verplichte eigen risico }\end{array}$ & 13,8 & 18,3 & 7,0 & 12,1 & 15,8 & 6,1 \\
\hline $\begin{array}{l}\text { Ik weet precies wanneer ik recht heb op } \\
\text { compensatie van het verplichte eigen risico }\end{array}$ & 3,9 & 9,1 & 2,8 & 6,0 & 14,0 & 4,3 \\
\hline \multicolumn{7}{|l|}{ Informatie } \\
\hline & $N=48$ & $N=60$ & $N=140$ & $N=167$ & $N=327$ & $N=702$ \\
\hline Informatie opgezocht & 2,7 & 29,1 & 2,0 & 2,8 & 25,4 & 2,1 \\
\hline
\end{tabular}

Noot: Bij deze analyses zijn alleen de mensen die denken recht te hebben op de compensatie of dit niet weten meegenomen.

Referentiegroep: geslacht $=0,61$ leeftijd $=60,1$, opleiding $=4,7$ 